\title{
Stable Transfectants of Human MCF-7 Breast Cancer Cells with Increased Levels of the Human Folate Receptor Exhibit an Increased Sensitivity to Antifolates
}

\author{
Koong-Nah Chung, Yutaka Saikawa, Tae-Hyun Paik, Katharine H. Dixon, Timothy Mulligan, \\ Kenneth H. Cowan, and Patrick C. Elwood \\ Medicine Branch, National Cancer Institute, National Institutes of Health, Bethesda, Maryland 20892
}

\begin{abstract}
A major problem in cancer therapy is tumor drug resistance such as is found with antifolates (e.g., methotrexate [MTX]). We are specifically interested in the role of the human folate receptor (hFR) in MTX resistance. To investigate whether transfection of hFR results in increased MTX uptake and increased drug sensitivity, human mammary carcinoma (MCF7) cells and Chinese hamster ovary cells (CHO) (cells which do not express detectable levels of $h F R$ ) were transfected with hFR cDNA. Stable human mammary carcinoma and Chinese hamster ovary transfectants expressing high levels of $h F R$ were selected for further analysis. Transfected cells which express increased levels of hFR grow more rapidly than mock transfected or wild type cells in media containing physiologic concentrations of folates. The hFR expressed by these cells is sorted to the plasma membrane and is functional as determined by cell surface binding of a radiolabeled folic acid derivative and by internalization of $\left[{ }^{3} \mathrm{H}\right]$ methotrexate. The stable transfectants that express increased levels of hFR are also more sensitive to MTX in physiologic concentrations of folates. We conclude that increased expression of hFR by human mammary carcinoma and Chinese hamster ovary cells cultured under these conditions results in an enhanced growth rate, increased folic acid binding, and increased MTX uptake and cytotoxicity. (J. Clin. Invest. 1993.91:1289-1294.) Key words: cell growth • drug resistance $\cdot$ folate binding proteins $\bullet$ folic acid $\bullet$ methotrexate
\end{abstract}

\section{Introduction}

Studies in normal and neoplastic human, and murine cells suggest that cellular resistance to methotrexate (MTX) ${ }^{1}$ cytotoxicity is commonly due to a defect in MTX transport (1-8). Although transport defects have been implicated in development

Address correspondence to Koong-Nah Chung, Medicine Branch, Building 10, Room 12N226, National Institutes of Health, 9000 Rockville Pike, Bethesda, MD 20892.

Received for publication 29 July 1992 and in revised form 30 October 1992.

1. Abbreviations used in this paper: $\mathrm{CHO}$, Chinese hamster ovary; CMV, cytomegalovirus; DMEM, minimal essential media without folic acid; hFR, human folate receptor; KB, human nasopharyngeal epidermoid carcinoma cells; MCF-7, human mammary carcinoma; MCS, multiple cloning site; MTX, methotrexate; PSF, penicillin/streptomycin/fungizone.

The Journal of Clinical Investigation, Inc.

Volume 91, April 1993, 1289-1294 of resistance to MTX, specific mutations or changes in expression of transport molecules have not been described. At least two receptor systems seem to be involved in MTX transport. The reduced folate/methotrexate transporter contained in murine L-1210 leukemia cells $(7,9,10)$ and human CCRF-CEM lymphoblastic cells $(11,12)$ has an apparent molecular weight ranging from 36 to $78 \mathrm{kD}$ on SDS-PAGE analysis (13-16) and shows preference for reduced folates and equal affinity for MTX. The second folate/MTX transport system consists of a membrane-bound folate receptor with high affinities for folates including folic acid. It is found in human nasopharyngeal epidermoid carcinoma (KB) cells, MA104 monkey kidney cells, T47D human mammary carcinoma cells, L-1210 and CCRFCEM cells, and its expression increases when cells are adapted to low folate concentrations (17-24). This folate receptor is a $40-\mathrm{kD}$ glycoprotein and in some cell lines appears to be responsible for internalization of folates and methotrexate. The folate receptor cDNA has been cloned and described (25-30).

In preliminary studies of KB cell sublines selected for MTX resistant phenotypes $(31,32)$, expression of human folate receptor (hFR) mRNA and protein were frequently reduced in parallel with decreased MTX uptake. These results suggest that hFR is an important determinant in MTX resistance or sensitivity in these cells. A potential problem in the interpretation of such studies is that when drug resistant cell lines are produced, gene products other than the one of interest may be induced or inhibited and these secondary changes may contribute to the observed phenotype. To circumvent this potential problem and to study the role of a single gene product ( the human folate receptor) in MTX sensitivity, we introduced recombinant KB cell cDNA encoding the hFR into human mammary carcinoma (MCF-7) and Chinese hamster ovary ( $\mathrm{CHO}$ ) cells (cells which normally do not express detectable levels of hFR), and asked whether increased hFR expression leads to increased MTX sensitivity. We present data which demonstrate that stably transfected MCF-7 and $\mathrm{CHO}$ cells expressing increased levels of hFR grow better in physiologic folate concentrations, have an increased surface binding of folic acid, internalize more MTX, and show increased sensitivity to MTX.

\section{Methods}

Materials. ${ }^{125}$ I-labeled pteroylglutamic acid (folic acid, $\left[{ }^{125} \mathrm{I}\right]$ histamine derivative, [1-carboxy-3- $(N) 2-\left(4-\left[{ }^{125}\right.\right.$ I] iodoimidazolyl] ethyl [carbonoyl]-1-pteroyl-amino propane) (histamine derivative of folic acid), $\left[{ }^{35} \mathrm{~S}\right]$ methionine and $\left[{ }^{35} \mathrm{~S}\right]$ cysteine were purchased from New England Nuclear, Boston, MA. Methotrexate was purchased from Sigma Chemical Co. (St. Louis, MO). $\left[3^{\prime}, 5^{\prime}, 7-{ }^{3} \mathrm{H}\right]$ MTX (sp act, 20 $\mathrm{Ci} / \mathrm{mmol}$ ) was purchased from Moravek Biochemicals (Brea, CA). Scintillation fluid was 3a70D from Research Products International (Mt. Prospect, IL). Acrylamide and low molecular weight markers were purchased from Bio-Rad Laboratories (Richmond, CA ). Agarose 
was obtained from Bethesda Research Laboratories (Gaithersburg, MD). All restriction enzymes and enzymes and reagents for radiolabeling cDNA probes were purchased from Promega Corp. (Madison, WI). 5[alpha- $\left.{ }^{32} \mathrm{P}\right] \mathrm{dCTP}$ and dGTP (each with a sp act of $>800 \mathrm{Ci} /$ mmol) were obtained from Amersham Corp. (Arlington Heights, IL). Nytran membranes were obtained from Schleicher \& Schuell (Keene, $\mathrm{NH}$ ). All other chemicals were of reagent grade or higher, and were purchased from Sigma Chemical Co., Fisher Scientific (Pittsburgh, PA), or J. T. Baker Inc. (Phillipsburg, NJ).

Plasmid construction. The $\mathrm{pRc} /$ cytomegalovirus (CMV) vector (Invitrogen Corp., San Diego, CA) contains a cytomegalovirus promotor and a neomycin resistance gene. The cDNA encoding hFR (FRP10) was isolated from a placental cDNA GT11 library (Elwood, P. C., K. Price, Y. Saikawa, S. T. Page, P. Pacheco, and K.-N. Chung, manuscript in preparation ) and subcloned at the EcoRI multiple cloning site (MCS) of pGEM4Z (Promega Corp.). The insert-purified FR-P10 cDNA containing EcoRI ends was blunt-ended using Klenow large fragment (33). The HindIII linearized $\mathrm{pRc} / \mathrm{CMV}$ expression vector was treated with Klenow large fragment and alkaline phosphatase, and vector was ligated with blunt-ended insert using T4 DNA ligase. Competent Escherichia coli (JM109) were transformed with the ligation mixture and recombinant plasmids were isolated by maxiprep kit (Qiagen, Inc., Chatsworth, CA ). The sense orientation of the folate receptor cDNA in $\mathrm{pRc} / \mathrm{CMV}$ vector ( $\mathrm{pRc} / \mathrm{P10})$ was verified by restriction enzyme digests. We designated the plasmid construct containing pRc/ CMV vector and the human nasopharyngeal epidermoid carcinoma (KB) cell folate receptor CDNA (FR-P10) as pRc/P10.

Transfection. For stable transfection of MCF-7 and CHO cells with $\mathrm{pRc} / \mathrm{P} 10$, we used the calcium phosphate method (34). MCF-7 and $\mathrm{CHO}$ cells were also transfected with $\mathrm{pRc} / \mathrm{CMV}$ vector only. We found that the wild type and neo control cells are identical in their phenotype. These wild type and transfected clones served as controls in our experiments. Stable transfectants of MCF-7 cells and $\mathrm{CHO}$ cells were clonally selected in $1 \mathrm{mg} / \mathrm{ml}$ geneticin sulfate (antibiotic G418; Gibco Laboratories, Grand Island, NY) and $500 \mu \mathrm{g} / \mathrm{ml} \mathrm{G418,} \mathrm{respectively,} \mathrm{using}$ cloning cylinders. 1,000 cells were plated per $10-\mathrm{cm}$ tissue culture plates, and $\sim 10$ clones were picked from each plate. Stable transfectants of both cell types are being maintained in cytotoxic concentrations of G418 $(200 \mu \mathrm{g} / \mathrm{ml})$. The clones were initially selected in minimal essential media (RMEM, $2.2 \mu \mathrm{M}$ folic acid; Gibco Laboratories) and then transferred to media containing low concentrations of folates (DMEM, 1-10 $\mathrm{nM}$ folates derived from the added fetal calf serum). Wild type and transfected cell lines have been maintained in DMEM for $>12 \mathrm{mo}$. For all experiments reported herein, cells were cultured in DMEM for $>6$ passages ( $>30$ doublings).

Immunoprecipitation of hFR. MCF-7 stable transfectants (designated as clones neo, A6, and A4) were plated in $3 \mathrm{ml}$ of DMEM, containing $10 \% \mathrm{FCS}, 100 \mathrm{U} / \mathrm{ml}$ penicillin, $100 \mu \mathrm{g} / \mathrm{ml}$ streptomycin, $0.25 \mu \mathrm{g} / \mathrm{ml}$ fungizone (PSF), and $200 \mu \mathrm{g} / \mathrm{ml} \mathrm{G} 418$, in $35-\mathrm{mm}$ wells (Falcon Plastics, Cockeysville, MD) at $37^{\circ} \mathrm{C}, 5 \% \mathrm{CO}_{2}$. Plating densities were adjusted so that cells were $75 \%$ confluent when we carried out the immunoprecipitation experiments. Cells were washed once with $2 \mathrm{ml}$ media containing no methionine or cysteine (Gibco Laboratories), and incubated in $2 \mathrm{ml}$ of the same media for $1 \mathrm{~h}$ at $37^{\circ} \mathrm{C}, 5 \% \mathrm{CO}_{2}$. Newly synthesized proteins were radiolabeled by pulsing the cells in 1 $\mathrm{ml}$ of the same media containing $100 \mu \mathrm{Ci}\left[{ }^{35} \mathrm{~S}\right]$ methionine and $100 \mu \mathrm{Ci}$ $\left[{ }^{35} \mathrm{~S}\right]$ cysteine for $1 \mathrm{~h}$ at $37^{\circ} \mathrm{C}, 5 \% \mathrm{CO}_{2}$. The cells were washed once $(2$ $\mathrm{ml}$ ) in media containing added cold methionine ( $15 \mathrm{mg} /$ liter; Gibco Laboratories) and cysteine ( $24 \mathrm{mg} / \mathrm{liter}$; Gibco Laboratories), and proteins were chased in this complete media $(2 \mathrm{ml})$ for $5 \mathrm{~h}$ at $37^{\circ} \mathrm{C}, 5 \%$ $\mathrm{CO}_{2}$. At the end of the chase period, cells were washed three times with (2 ml each) ice-cold PBS, pH 7.4 (10 mM Na-phosphate, $150 \mathrm{mM}$ $\mathrm{NaCl}$; Biofluids Inc., Rockville, MD). Cells were scraped into ( $5 \mathrm{ml})$ ice cold PBS, $20 \mathrm{mM}$ EDTA, pH 7.4, and 0.3\% PMSF, and centrifuged at $3,000 \mathrm{~g}$ for $15 \mathrm{~min}$ at $4^{\circ} \mathrm{C}$. Cell pellets were resuspended in ice-cold ( $1 \mathrm{ml}$ ) $10 \mathrm{mM}$ potassium phosphate, $\mathrm{pH} 7.4$, and freeze-thawed twice. Cell membranes were spun for $15 \mathrm{~min}$ at $13,000 \mathrm{~g}$ at $4^{\circ} \mathrm{C}$. Membrane proteins were solubilized in $1 \mathrm{ml}$ PBS containing $1 \%$ Triton X-100 (vol/vol) for $18 \mathrm{~h}$ at $4^{\circ} \mathrm{C}$ on a shaking platform. (All subsequent steps were carried out in buffers containing PMSF). Debris was removed by centrifugation for $15 \mathrm{~min}$ at $13,000 \mathrm{~g}$ at $4^{\circ} \mathrm{C}$. Supernatant samples were used for immunoprecipitation as follows: Protein A-Sepharose (Sigma Chemical Co.) was prewashed in immunoprecipitation buffer $(10 \mathrm{mM}$ Tris, $150 \mathrm{mM} \mathrm{NaCl}, 2 \mathrm{mM}$ EDTA, pH 7.4, and 1\% Triton X-100) and resuspended 1:1 ( vol/vol) in immunoprecipitation buffer. Protein samples were preabsorbed with $100 \mu$ l of prewashed Protein-A Sepharose for $2 \mathrm{~h}$ at $4^{\circ} \mathrm{C}$ and centrifuged for $1 \mathrm{~min}, 14,000 \mathrm{~g}$, at $4^{\circ} \mathrm{C}$. Preabsorbed protein samples were assayed for protein by the Biuret method (Pierce Chemical Co., Rockford, IL) and volumes were adjusted to give identical protein concentrations. BSA was used as the standard. Protein samples ( $10 \mu \mathrm{g}$ each) were immunoprecipitated with $50 \mu \mathrm{l}$ rabbit anti-hFR antiserum in $750 \mu \mathrm{l}$ immunoprecipitation buffer containing $0.1 \%$ SDS for $3 \mathrm{~h}$ at $25^{\circ} \mathrm{C}$. Immunoprecipitates were incubated with $100 \mu \mathrm{l}$ Protein A-Sepharose for $30 \mathrm{~min}$ at room temp and washed four times ( 1 $\mathrm{ml}$ ) with immunoprecipitation buffer. SDS-PAGE sample buffer ( 50 $\mu$ l consisting of $0.125 \mathrm{M}$ Tris, pH $6.8,2 \%$ SDS, $20 \%$ glycerol, $0.08 \%$ bromophenol blue, and $100 \mathrm{mM}$ DL-dithiothreitol) was added to the final Protein-A Sepharose pellets. Samples were boiled for $5 \mathrm{~min}$ and Protein-A Sepharose pelleted in the microcentrifuge. Supernatants ( 50 $\mu \mathrm{l})$ and prestained low molecular weight markers (Bio-Rad Laboratories) were electrophoresed on a $12.5 \%$ SDS-PAGE and the gel was treated three times ( $15 \mathrm{~min}$ each) with $50 \%$ methanol and $10 \%$ acetic acid, rinsed once with $\mathrm{H}_{2} \mathrm{O}$, and incubated for $1 \mathrm{~h}$ in Enlightening (New England Nuclear). After drying, the gel was autoradiographed at $-70^{\circ} \mathrm{C}$ in cassettes with two intensifying screens.

$R N A$ slot blot. Total RNA $(10 \mu \mathrm{g})$ isolated from stably transfected clones of MCF-7 cells was transferred to Nytran membranes by means of a slot blot apparatus (Schleicher \& Schuell, Inc.). The blot was prehybridized, hybridized with radiolabeled FR-P10, and washed as previously described (25). Under these conditions, a single species of mRNA ( 1,100 bp) hybridizes with radiolabeled hFR-P10 cDNA on Northern analysis of cells expressing the hFR. Signal intensities of each band were quantitated using a spectrophotometer (DU65; Beckman Instruments, Inc., Fullerton, CA) equipped with a densitometer. Hybridization with radiolabeled actin was used to correct for RNA loaded.

Growth studies. Stable transfectants of wild type MCF-7 cells, were seeded at 50,000 cells / $3 \mathrm{ml}$ in DMEM containing $10 \%$ FCS, PSF, and $200 \mu \mathrm{g} / \mathrm{ml} \mathrm{G} 418$ in $35 \mathrm{~mm}$ wells, at $37^{\circ} \mathrm{C}, 5 \% \mathrm{CO}_{2}$. Cells were harvested $5 \mathrm{~d}$ later. Cells were rinsed twice with $(3 \mathrm{ml})$ cold PBS and solubilized as described above ( see immunoprecipitation studies). Protein concentration in each solubilized sample was determined as described above. Growth experiments were carried out three separate times. Values from separate experiments varied by $<10 \%$.

Cell surface folic acid binding assay. MCF-7 stable transfectants were plated as described above (see immunoprecipitation studies). KB cells were maintained in the same media without G418. Plating densities were adjusted so that cells were $75 \%$ confluent for the folic acid binding assays. The form of radiolabeled folic acid used is an iodinated, histamine derivative of folic acid obtained from New England Nuclear. Cells were washed two times with $(3 \mathrm{ml})$ ice-cold pH 4.5 saline $(10 \mathrm{mM}$ $\mathrm{Na}$-acetate, $150 \mathrm{mM} \mathrm{NaCl}$ ) to dissociate surface-bound folates from cell surface folate receptor. Cell monolayers were subsequently washed two times with ( $3 \mathrm{ml}$ ) ice-cold PBS, $\mathrm{pH} 7.4$, to return the $\mathrm{pH}$ to neutral. For cell surface-binding of radiolabeled folic acid, cells were incubated in $2 \mathrm{ml}$ of ice-cold DMEM (without FCS), containing iodinated, histamine derivative of folic acid $(20,000 \mathrm{cpm}$ total added to $50 \mathrm{nM}$ cold folic acid) and $50 \mu \mathrm{g} / \mathrm{ml} \mathrm{BSA}$ for $15 \mathrm{~min}$ in an ice- $\mathrm{H}_{2} \mathrm{O}$ bath. To determine specific cell surface binding ( $\mathrm{cpm} / \mathrm{mg}$ protein), parallel experiments were performed in which 1,000-fold excess of cold folic acid was added. The monolayer was washed two times with (with $3 \mathrm{ml} \mathrm{each}$ ) ice-cold PBS, pH 7.4. Cells were solubilized as described above (see immunoprecipitation studies). Supernatant samples were counted in a gamma counter (55B; Beckman Instruments, Inc.) at $\sim 70 \%$ efficiency. Protein concentration in each solubilized sample was determined as described above. The data reflect specific cell surface-binding of radioligand, since in the presence of 1,000 -fold excess of nonradioac- 
tive folic acid, the amount of folic acid binding was $<5 \%$ of that seen in controls. Cell surface folic acid binding experiments were carried out three separate times. Values from separate experiments varied by $<10 \%$.

Folic acid binding assay. Folic acid binding assays on detergent-solubilized protein extracts were carried out as previously described (19).

Methotrexate transport studies. MCF-7 stable transfectants and KB cells were plated as described above ( see folic acid binding assays). Cell monolayers were washed two times with $(3 \mathrm{ml})$ ice-cold $\mathrm{pH} 4.5$ saline and two times with $(3 \mathrm{ml})$ ice-cold PBS, $\mathrm{pH}$ 7.4. For internalization of ${ }^{3} \mathrm{H}$-MTX, cells were incubated in $2 \mathrm{ml}$ of prewarmed $\left(37^{\circ} \mathrm{C}\right)$ DMEM (without FCS or other additives), containing $50 \mu \mathrm{g} / \mathrm{ml} \mathrm{BSA}$, and $2 \mu \mathrm{M}$ [ ${ }^{3} \mathrm{H}$ ]MTX, for $30 \mathrm{~min}$ at $37^{\circ} \mathrm{C}, 5 \% \mathrm{CO}_{2}$. To determine specific MTX internalization ( $\mathrm{pmol} / \mathrm{mg}$ protein), parallel experiments were performed in the presence of 500 -fold excess cold MTX. To differentiate transport mediated by $\mathrm{hFR}$ from the reduced folate transporter, parallel experiments were run in the presence of molar ( 100 -fold) excess of cold folic acid which inhibits transport via hFR. The monolayer was washed once with $2 \mathrm{ml}$ ice-cold PBS ( $\mathrm{pH} 7.5$ ), once with $2 \mathrm{ml} \mathrm{pH} 4.5$ saline to remove surface-bound ${ }^{3} \mathrm{H}-\mathrm{MTX}$, and finally with $2 \mathrm{ml}$ of ice-cold PBS ( $\mathrm{pH} 7.5$ ). Cells were solubilized as described above (see immunoprecipitation studies). Samples $(500 \mu \mathrm{l})$ were added to $10 \mathrm{ml}$ of liquid scintillation cocktail and counted on a liquid scintillation counter (Tri-carb; Packard Instrument Co., Inc., Downers Grove, IL) at $\sim 50 \%$ efficiency. The data reflect specific internalization of ${ }^{3} \mathrm{H}-$ MTX, since in the presence of excess nonradiolabeled MTX, MTX internalization was $<10 \%$ of total uptake for all data points. Protein concentration in each solubilized sample was determined as described above. The ${ }^{3} \mathrm{H}-\mathrm{MTX}$ transport studies were carried out three separate times. Values from separate experiments varied by $<10 \%$.

Methotrexate sensitivity. MCF-7 stable transfectants (clones neo, $\mathrm{A} 4$, and $\mathrm{A6}$ ) and $\mathrm{CHO}$ stable transfectants ( $\mathrm{CHO}$, clones 1 and 2 ) were plated as described above (see growth studies). After $24 \mathrm{~h}$ (to allow the cells to attach to the plates), medium containing increasing concentrations of MTX $(0-1,000 \mathrm{nM})$ was added. Cells were harvested $5 \mathrm{~d}$ later. Cells were rinsed twice with $3 \mathrm{ml}$ cold PBS, and solubilized as described above (see immunoprecipitation studies). The protein concentration of each sample was determined as described above. The MTX sensitivity studies were carried out three separate times and the values from separate experiments varied by $<5 \%$.

\section{Results and Discussion}

Previous studies (32) have demonstrated a correlation between decreased internalization of methotrexate (MTX) and reduced

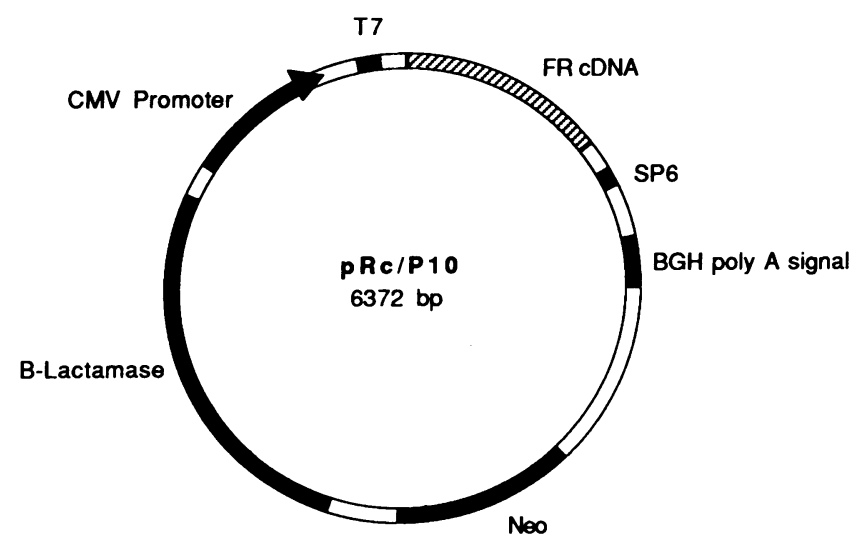

Figure 1. pRc/P10 construct. The $\mathrm{pRc} / \mathrm{P} 10$ construct $(6,372 \mathrm{bp})$ consists of the pRc/CMV vector (5,452 bp) and cDNA insert ( 920 bp).

\section{MCF-7 CLONES neo A6 A4}

MW std

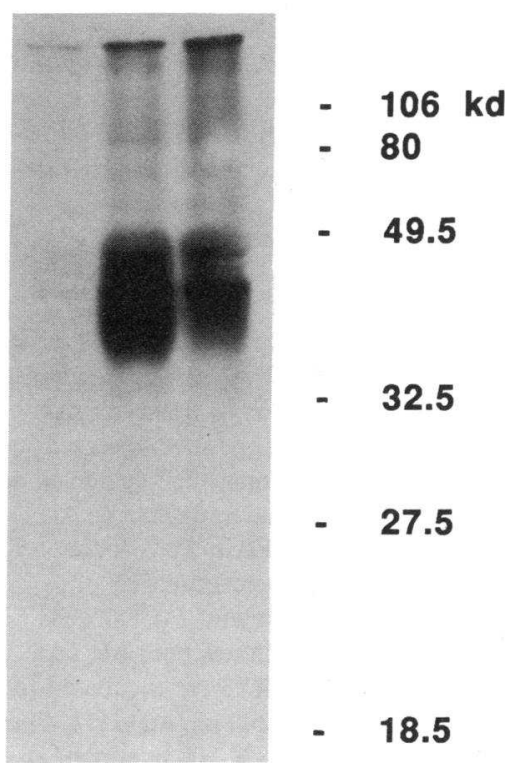

Figure 2. Immunoprecipitation of hFR protein. MCF-7 cells (clones neo, A6, and A4) were incubated in $35-\mathrm{mm}$ plates in DMEM containing $10 \%$ FCS, PSF, and $200 \mu \mathrm{g} / \mathrm{ml} \mathrm{G} 418$. Newly synthesized proteins were radiolabeled with $\left[{ }^{35} S\right]$ methionine and $\left[{ }^{35} \mathrm{~S}\right]$ cysteine, and immunoprecipitated using rabbit anti-hFR antiserum as described in Methods. The immunoprecipitates were electrophoresed on $12.5 \%$ SDS-PAGE and the autoradiogram is shown. (Lane 1) $10 \mu \mathrm{g}$ of membrane proteins of neo clone. (Lane 2) $10 \mu \mathrm{g}$ of membrane proteins of A6 clone. (Lane 3) 10 $\mu \mathrm{g}$ of membrane proteins of A4 clone. The molecular weight markers are indicated.

expression of the folate receptor in KB clones selected for resistance to MTX. To determine if increased expression of the folate receptor contributes to MTX cytotoxicity, we transfected hFR cDNA into mammalian cells. Fig. 1 shows the plasmid construct containing $\mathrm{pRc} / \mathrm{CMV}$ vector and the human $\mathrm{KB}$ cell folate receptor CDNA (FR-P10), which we designate as $\mathrm{pRc} / \mathrm{P} 10$. Compared to the previously reported KB cell c32 cDNA (25), the FRP10 cDNA contains an identical open reading frame, but shorter $5^{\prime}$ and $3^{\prime}$ untranslated regions. We chose this construct because the length of the 5'UTR may affect the efficiency of translation or stability of the transcript and because the 5UTR of c32 contains several termination codons upstream to the translational initiation site.

Since human mammary carcinoma (MCF-7) cells do not express detectable levels of hFR mRNA or protein (25), we transfected MCF-7 cells with $\mathrm{pRc} / \mathrm{P} 10$ and obtained clones that stably express hFR. We selected a clone transfected with vector alone (neo), and two clones transfected with $\mathrm{pRc} / \mathrm{P} 10$ (clones A6 and A4) for further analysis. As determined by immunoprecipitation of radiolabeled newly synthesized proteins, stable transfectants (clones A6 and A4) express high levels of the hFR protein when compared to control cells (neo clone) which do not contain detectable levels of $\mathrm{hFR}$, as shown in Fig. 2. The A6 clone expressed the highest level and A4 clone expressed the next highest level of hFR.

To assess the hFR levels more quantitatively, the level of hFR transcripts expressed by stable MCF-7 transfectants were determined by slot blot analysis of total cellular RNA. Fig. $3 A$ shows that clones A6 and A4 express increased levels of hFR transcripts. As previously reported, MCF-7 cells transfected with $\mathrm{pRc} / \mathrm{CMV}$ vector alone (neo clone) did not express detectable levels of hFR transcript, represented in Fig. $3 A$ as "u.d." (undetectable). 

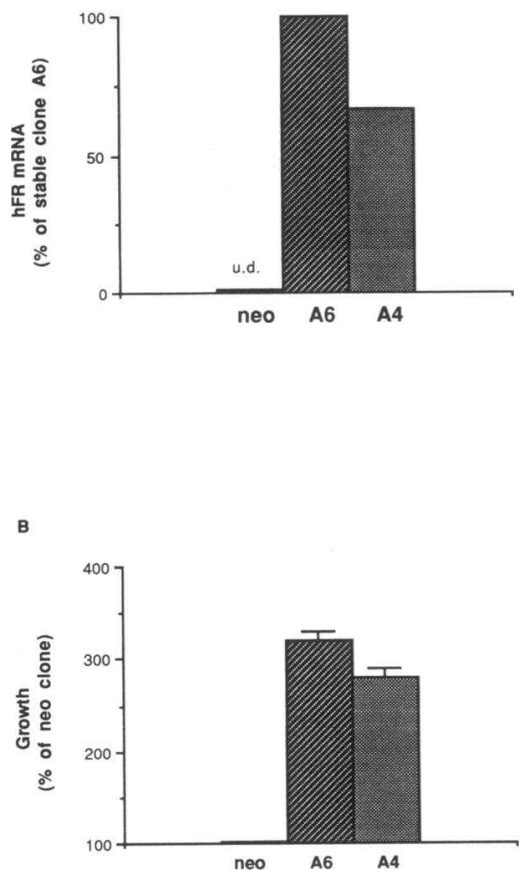

Figure 3. (A) Slot blot analysis of mRNA. The slot blot containing total RNA from each transfectant of MCF-7 cells was prepared and hybridized as described in Methods. The mRNA levels were detected by using a radiolabeled hFR cDNA probe and the intensity of the signal for each clone was quantitated using a densitometer.

Since clone A6 expressed the highest level, all values were normalized to the transcript abundance observed in clone A6. The neo clone had undetectable (u.d.) hFR mRNA levels. (B) Determination of growth. MCF-7 cells (clones neo, A6, and A4) were incubated for $5 \mathrm{~d}$ in DMEM containing $10 \%$ FCS, PSF, and $200 \mu \mathrm{g} / \mathrm{ml} \mathrm{G} 418$. Cells were solubilized with PBS containing $1 \%$ Triton X-100 overnight at $4^{\circ} \mathrm{C}$. Supernatant was assayed for protein, and results are expressed as a percentage of protein in control cells (neo clone, $100 \mu \mathrm{g}$ ).

Next we examined whether clones A6 and A4 expressing increased levels of hFR replicate faster than the neo clone in low concentrations of folates. We found a positive relationship between hFR expression levels and growth in low concentrations of folates as shown in Fig. $3 \mathrm{~B}$. Stable transfectants expressing increased levels of hFR (A6 and A4) grew 3.2- and 2.8-fold faster than cells transfected with vector alone (neo) or parental MCF-7 cells (data not shown). Similar findings were recently reported (35).

The hFR expressed by clones A6 and A4 is sorted to the plasma membrane and binds ligand. Fig. $4 \mathrm{~A}$ shows that clones A6 and A4 bind high levels of radiolabeled folic acid (iodinated, histamine derivative of folic acid) at the cell surface, at levels (50-70\%) approaching that seen in KB cells (normally, a high hFR expressing cell line). Fig. $4 A$ also shows that the neo clone did not contain detectable levels of cell surface folic acid binding ("u.d."). We have also carried out our studies on the cell surface-binding of this radioligand for $30 \mathrm{~min}$ at $0^{\circ} \mathrm{C}$ and found no difference between surface-binding at 15 and $30 \mathrm{~min}$ (data not shown). We have performed preliminary ligandbinding studies using the physiological circulating form of folate (5-methyltetrahydrofolate) and observed identical results (data not shown). When compared to control cells (neo clone), the solubilized total cellular extracts of clones A6 and A4 also showed proportionate increases in their total folic acid binding capacity at levels (40-50\%) approaching that seen in KB cells (data not shown).

To show that the folate receptor is functional at the cell surface in these transfectants, we measured specific internalization of $\left[{ }^{3} \mathrm{H}\right]$ methotrexate. As shown in Fig. $4 \mathrm{~B}$, stable transfectants expressing elevated levels of hFR show increased ${ }^{3} \mathrm{H}$ -

MTX uptake when cultured in DMEM: clones A6 and A4 internalize 3.2- and 2.4-fold more ${ }^{3} \mathrm{H}$-MTX than cells mock transfected with vector alone (neo). Fig. $4 B$ also shows that MTX transport found in clones A6 and A4 are approaching levels found in KB cells which internalize 3.6-fold more ${ }^{3} \mathrm{H}$ MTX than the neo clone. Interestingly, the neo clone demonstrated folic acid insensitive MTX uptake consistent with the absence of cell surface folic acid binding. In contrast, MTX uptake by the A6 and A4 transfectants is inhibited by both cold MTX (>90\%) and folic acid (>60\%). The absence of cell surface folic acid binding and the lack of inhibition of MTX influx in the presence of excess folic acid suggest that MCF-7 cells have a hFR-independent method of accumulating MTX such as the reduced folate transporter (1-8). However, transfection of MCF-7 cells with hFR appears to further increase (2.4- and 3.2-fold) their ability to internalize additional MTX.

To determine whether the differences in MTX uptake are reflected in MTX cytotoxicity, growth inhibition in increasing concentrations of MTX was measured for each transfectant. As shown in Fig. $5 \mathrm{~A}$, clones A4 and A6 are 8- and 10-fold respectively more sensitive to MTX than cells mock transfected with vector alone (neo) and wild type MCF-7 cells (data not shown). These results also demonstrate that the growth of mock transfectants was not completely inhibited, even at MTX concentrations 100 -fold greater than that which inhibited $>99 \%$ of the growth of clones A4 and A6. The experiments on the sensitivity to MTX were carried out for $5 \mathrm{~d}$. We have found
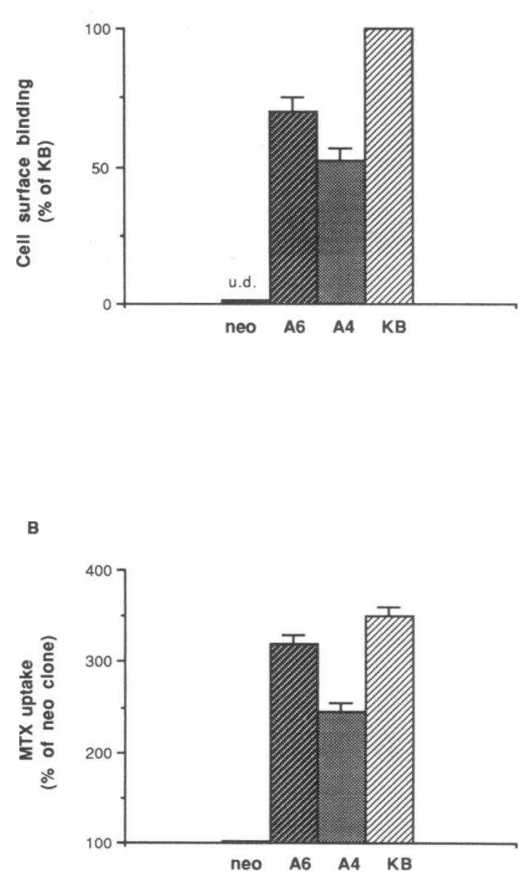

Figure 4. $(A)$ Determination of cell surface folic acid binding. MCF-7 cells (clones neo, A6, and A4) were incubated in $35-\mathrm{mm}$ plates in DMEM containing $10 \%$ FCS, PSF, and $200 \mu \mathrm{g} / \mathrm{ml} \mathrm{G} 418$. $\mathrm{KB}$ cells were grown in DMEM containing 10\% FCS and PSF. After dissociating surface-bound folates from cell surface folate receptors with acid saline as described in Methods, cells were incubated with radiolabeled folic acid for 15 min at $0^{\circ} \mathrm{C}$ with or without excess cold ligand. Aliquots of solubilized cells were counted and the results are expressed as cell surface binding relative to that observed in $\mathrm{KB}$

cells. $(B)$ Determination of $\left[{ }^{3} \mathrm{H}\right]$ methotrexate transport. MCF-7 cells from each clone were incubated in DMEM containing $10 \%$ FCS, $\mathrm{PSF}$, and $200 \mu \mathrm{g} / \mathrm{ml} \mathrm{G} 418$. KB cells were grown in DMEM containing $10 \%$ FCS and PSF. After dissociating surface-bound folates from cell surface folate receptor as described in Methods, cells were allowed to internalize $\left[{ }^{3} \mathrm{H}\right]$ methotrexate for $30 \mathrm{~min}$ at $37^{\circ} \mathrm{C}$. Aliquots of solubilized cells were counted, and the results from clones A6 and A4, and $\mathrm{KB}$ cells are expressed as a percentage of control cells (neo clone). 
A MCF-7 cells

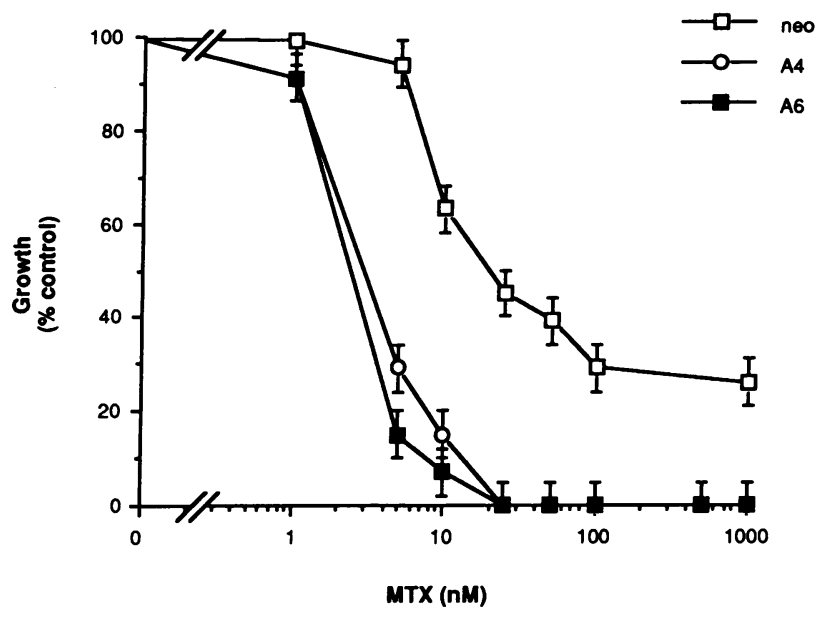

B CHO cells

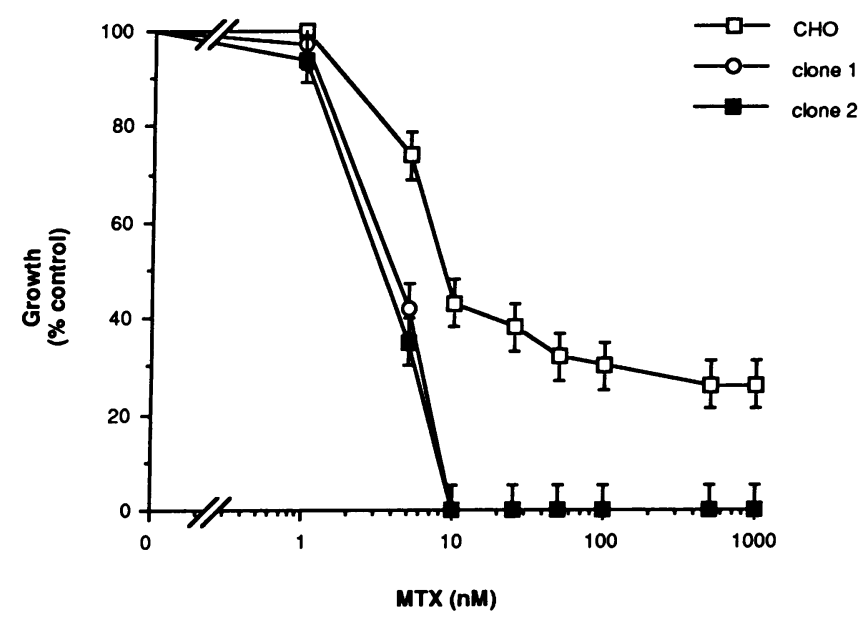

Figure 5. Determination of MTX sensitivity in transfected cells. MCF-7 cells $(A)$ and $\mathrm{CHO}$ cells $(B)$ from each clone were incubated for $5 \mathrm{~d}$ in DMEM containing 10\% FCS, PSF, and $200 \mu \mathrm{g} / \mathrm{ml} \mathrm{G} 418$ with increasing MTX concentrations. After solubilization of cells, the supernatant was assayed for protein. Results are expressed as a percentage of protein at each MTX concentration relative to total protein in the absence of MTX for each separate clone.

identical results when the experiments were carried out for $10 \mathrm{~d}$ (data not shown). Identical results were observed when growth inhibition was determined by cell counts.

We have confirmed our findings in MCF-7 cells by establishing and characterizing Chinese hamster ovary ( $\mathrm{CHO}$ ) transfectants which stably express functional hFR. Fig. $5 B$ shows that when compared to control cells, these stable transfectants (clones 1 and 2) are approximately 5-fold more sensitive to MTX. Furthermore, compared to control $\mathrm{CHO}$ cells, clones 1 and 2 also bind more radiolabeled folic acid at the cell surface, internalize 2 to 3 -fold more ${ }^{3} \mathrm{H}$-MTX and grow 4-fold better in physiologic concentrations of folates (data not shown).

In these studies, we have observed that sensitivity to MTX depends on the concentration of folates contained in the medium. When folate concentrations are low, stable transfectants that express elevated levels of hFR are more sensitive to MTX than wild type cells (Fig. 5, $A$ and $B$ ). However, in standard medium, we did not observe a difference in MTX sensitivity between neo and A4 / A6 clones (data not shown). Since standard medium (e.g., RMEM) contains $2.2 \mu \mathrm{M}$ folic acid and since intracellular folate concentrations are a direct function of folate concentration in culture medium (36), it is likely that the reduced MTX cytotoxicity that we observed in transfectants cultured in RMEM results from competitive inhibition of MTX transport by folic acid [which has a higher affinity than MTX for the hFR]. This effect of folic acid concentration on MTX cytotoxicity has also been observed in KB cells (36).

In conclusion, we have established stable transfectants which express high levels of hFR, to levels approaching that found in KB cells. These clones show that in physiologic concentrations of folic acid, increased levels of hFR expression are related to cell growth, folic acid binding and transport, MTX transport, and MTX sensitivity. We have also observed small but reproducible differences in the expression of hFR between clones A6 and A4 which are consistent with different biochemical assays for hFR function. Although it is possible that other factors may be different between these two clones and their controls, there appears to be a correlation between levels of hFR and function of the hFR.

\section{References}

1. Assaraf, Y. G., and R. T. Schimke. 1987. Identification of methotrexate transport deficiency in mammalian cells using fluoresceinated methotrexate and flow cytometry. Proc. Natl. Acad. Sci. USA. 84:7154-7158.

2. Flintoff, W. F., and C. R. Nagainis. 1983. Transport of methotrexate in Chinese hamster ovary cells: a mutant defective in methotrexate uptake and cell binding. Arch. Biochem. Biophys. 223:433-440.

3. Frei, E., III, A. Rosowsky, J. E. Wright, C. A. Cucchi, J. A. Lippke, T. J. Ervin, J. Jolivet, and W. A. Haseltine. 1984. Development of methotrexate resistance in a human squamous cell carcinoma of the head and neck in culture. Proc. Natl. Acad. Sci. USA. 81:2873-2877.

4. Galivan, J. 1981. 5-methyltetrahydrofolate transport by hepatoma cells and methotrexate-resistant subline in culture. Cancer Res. 41:1757-1762.

5. Schuetz, J. D., L. H. Matherly, E. H. Westin, and I. D. Goldman. 1988. Evidence for a functional defect in the translocation of the methotrexate transport carrier in a methotrexate-resistant murine L1210 leukemia cell line. J. Biol. Chem. 263:9840-9847.

6. Sherwood, S. W., Y. G. Assaraf, A. Molina, and R. T. Schimke. 1990. Flow cytometric characterization of antifolate resistance in cultured mammalian cells using fluoresceinated methotrexate and daunorubicin. Cancer Res. 50:49464950 .

7. Sirotnak, F. M. 1985. Obligate genetic expression in tumor cells of a fetal membrane property mediating "folate" transport. Biological significance and implications for improved therapy of human cancer. Cancer Res. 45:3992-4000.

8. Underhill, T. M., and W. F. Flintoff. 1989. Complementation of a methotrexate uptake defect in Chinese hamster ovary cells by DNA-mediated gene transfer. Mol. Cell. Biol. 9:1754-1758.

9. Goldman, I. D., and L. H. Matherly. 1986. Membrane Transport of Antineoplastic Agents International Encyclopedia of Pharmacology and Therapeutics. Section 118. Pergamon Press, Oxford. 283-302.

10. Henderson, G. B., and E. M. Zevely. 1984. Affinity labeling of the 5-methyltetrahydrofolate/methotrexate transport protein of $\mathrm{L} 1210$ cells by treatment with an $\mathrm{N}$-hydroxysuccinimide ester of $\left[{ }^{3} \mathrm{H}\right]$ methotrexate. J. Biol. Chem. 259:4558-4562.

11. Henderson, G. B. 1990. Folate-binding proteins. Annu. Rev. Nutr. 10:319-335.

12. Jansen, G., G. R. Westerhof, M. J. A. Jarmuszewski, I. Kathmann, G. Rijksen, and J. H. Schornagel. 1990. Methotrexate transport in variant human CCFR-CEM leukemia cells with elevated levels of the reduced folate carrier. $J$. Biol. Chem. 265:18272-18277.

13. Fan, J., K. S. Vitol, and F. M. Huennekens. 1991. Biotin derivatives of methotrexate and folate synthesis and utilization for affinity purification of two membrane-associated folate transporters from L1210 cells. J. Biol. Chem. 266:14862-14865.

14. Matherly, L. H., C. A. Czajkowski, and S. M. Angeles. 1991. Identification of a highly glycosylated methotrexate membrane carrier in K 562 human erythro- 
leukemia cells up-regulated for tetrahydrofolate cofactor and methotrexate transport. Cancer Res. 51:3420-3426.

15. Price, E. M., M. Ratnam, K. Rodeman, and J. H. Freischeim. 1988. Characterization of the methotrexate transport pathway in murine L1210 leukemia cells: involvement of a membrane receptor and a cytosolic protein. Biochemistry. 27:7853-7858.

16. Yang, C. H., F. M. Sirotnak, and L. S. Mines. 1988. Further studies on novel class of genetic variants of the $\mathrm{L} 1210$ cell with increased folate analogue transport inward. J. Biol. Chem. 263:9703-9709.

17. Antony, A. C., M. A. Kane, R. M. Portillo, P. C. Elwood, and J. F. Kolhouse. 1985. Studies of the role of a particulate folate-binding protein in the uptake of 5-methyltetrahydrofolate by cultured human KB cells. J. Biol. Chem. 260:14911-14917.

18. Deutsch, J. C., P. C. Elwood, R. M. Portillo, M. G. Macey, and J. F. Kolhouse. 1989. Role of the membrane-associated folate binding protein (folate receptor) in methotrexate transport by human KB cells. Arch. Biochem. Biophys. 274:327-337.

19. Elwood, P. C., M. A. Kane, R. M. Portillo, and J. F. Kolhouse. 1986. The isolation, characterization, and comparison of the membrane-associated and soluble folate-binding proteins from KB cells. J. Biol. Chem. 261:15416-15423.

20. Henderson, G. B., J. M. Tsuji, and H. P. Kumar. 1988. Mediated uptake of folate by a high-affinity binding protein in sublines of L1210 cells adapted to nanomolar concentrations of folate. J. Membr. Biol. 101:247-258.

21. Jansen, G., I. Kathmann, B. C. Rademaker, B. J. M. Braakhuis, G. R. Westerhof, G. Rijksen, and J. H. Schornagel. 1989. Expression of a folate binding protein in L1210 cells grown in low folate medium. Cancer Res. 49:1959-1963.

22. Kane, M. A., R. M. Portillo, P. C. Elwood, A. C. Antony, and J. F. Kolhouse. 1986. The influence of extracellular folate concentration on methotrexate uptake by human KB cells. J. Biol. Chem. 261:44-49.

23. Kane, M. A., P. C. Elwood, R. M. Portillo, A. C. Antony, and J. F Kolhouse. 1986. The interrelationship of the soluble membrane-associated folate binding proteins in human KB cells. J. Biol. Chem. 261:15625-15631.

24. Kane, M. A., and S. Waxman. 1989. Biology of disease: role of folate binding proteins in folate metabolism. Lab. Invest. 60:737-746.

25. Elwood, P. C. Molecular cloning and characterization of the human folate-binding protein cDNA from placenta and malignant tissue culture (KB) cells. 1989. J. Biol. Chem. 264:14893-14901.
26. Lacey, S. W., J. M. Sanders, K. G. Rothberg, R. G. W. Anderson, and B. A. Kamen. 1989. Complementary DNA for the folate binding protein correctly predicts anchoring to the membrane by glycosyl-phosphatidylinositol. J. Clin. Invest. 84:715-720.

27. Sadasivan, E., and S. P. Rothenberg. 1989. The complete amino acid sequence of a human folate binding protein from $\mathrm{KB}$ cells determined from the cDNA. J. Biol. Chem. 264:5806-5811.

28. Brigle, K. E., E. H. Westin, M. T. Houghton, and I. D. Goldman. 1991. Characterization of two cDNAs encoding folate-binding proteins from L1210 murine leukemia cells. Increased expression associated with a genomic rearrangement. J. Biol. Chem. 266:17243-17249.

29. Campbell, I. G., T. A. Jones, W. D. Foulkes, and J. Trowsdale. 1991. Folate-binding protein is a marker for ovarian cancer. Cancer Res. 51:5329_ 5338.

30. Coney, L. R., A. Tomassetti, L. Carayannopoulos, V. Frasca, B. A. Kamen, M. I. Colnaghi, and V. R. Zurawski, Jr. 1991. Cloning of a tumor-associated antigen: MOv18 \& MOv19 antibodies recognize a folate-binding protein. Cancer Res. 51:6125-6132.

31. Knight, C. B., P. C. Elwood, and B. A. Chabner. 1988. The human folate receptor in $\mathrm{KB}$ cells is altered in transport mediated, acquired methotrexate resistance. Blood. 72:274A

32. Saikawa, Y., and P. C. Elwood. 1990. Decreased human folate receptor (hFR) expression is associated with acquired methotrexate resistance. Blood. 76:164A.

33. Sambrook, J., E. F. Fritsch, and T. Maniatis. 1989. Molecular Cloning: A Laboratory Handbook. Cold Spring Harbor Laboratory, Cold Spring Harbor, NY.

34. Cullen, B. R. 1987. Use of eukaryotic expression technology in the functional analysis of cloned genes. Methods Enzymol. 152:684-704.

35. Matsue, H., K. G. Rothberg, A. Takashima, B. A. Kamen, and R. G. Anderson. 1992. Folate receptor allows cells to grow in low concentrations of 5-methyltetrahydrofolate. Proc. Nat. Acad. Sci. USA. 89:6006-6009.

36. Kane, M. A., P. C. Elwood, R. M. Portillo, V. Najfeld, A. Finley, S. Waxman, and J. F. Kolhouse. 1988. Influence on immunoreactive folate-binding proteins of extracellular folate concentration in cultured human cells. J. Clin. Invest. 81:1398-1406. 